\title{
Digital Teaching Competence and Space Competence with TPACK in Social Sciences
}

\author{
https://doi.org/10.3991/ijet.v15i19.14923 \\ Isabel María Gómez-Trigueros \\ University of Alicante, Alicante, Spain \\ isabel.gomez@ua.es
}

\begin{abstract}
Research on training in knowledge related to geolocation with technologies shows the training potentials and limitations that these resources offer for teachers in training. This study examines the perceptions of the instructional effectiveness of mobile devices and geolocation software, by analyzing the performance in the TPACK skills dimensions of future teachers. A mixed methodology has been implemented, with a descriptive cross-sectional approach as well as inferential analysis based on a questionnaire and the tasks carried out by the sample. The results show a poor didactic use of technologies while confirming the acquisition of knowledge about geolocation. This corroborates the benefits of applying an improvement in the digital competence of teachers in training.
\end{abstract}

Keywords-Geolocation, Digital Teacher Competence, training, LKT, teacher training.

\section{Introduction}

In recent years, we have witnessed a pedagogical change throughout Europe and in the world with the aim of giving a strong response to the needs related to teacher training in the didactic-technology binomial.

The concept of competence [1] suggests a set of basic capacities, abilities and / or skills, which are in the essential learning for citizens within the framework of the Information and Knowledge Society (IKS). Similarly, skills such as the ability to understand spatial, formal, and data terms and concepts are required. The understanding of spatial concepts refers to the so-called spatial ability and the set of capabilities related to the positioning, location and understanding of the territory in the area of geography.

Although there is no consensus regarding the definition of spatial competence (SC), the numerous works that have dealt with the subject converge in characterizing it as the ability to represent, generate, remember and transform symbolic nonlinguistic information $[2,3]$. Citizens must be able to read, understand and use a plan or map, to be able to orient themselves in space. In this sense, future teachers, whose task is to train their students in competencies, must not only have the spatial competence to be transmitters and teachers of such knowledge, but they must also appropri- 
ate the didactic potential of the Information and Communication Technologies (ICT) for this purpose. The current question is how to implement teaching and learning (TL) models that allow join content, pedagogies and technologies to be brought together in a dynamic and inclusive way. Thus, various options emerge, seeking to resolve this complex symbiosis such as the Technological Pedagogical Content Knowledge (TPACK) model [4]. This model proposes, among other aspects, the conjunction between the so-called Basic Knowledge of the Teacher [5] and the novel ICT resources $[6,7]$.

In this sense, this study focuses on the achievement of the following objectives: the first, to assess the level of geospatial competence of teachers in training; the second, to know their perception regarding the use of technologies for teaching; the third, study and assess the importance they attach to manipulative, didactic and pedagogical training of technological resources in their university training and, lastly, assess progress in geospatial competence at the end of the intervention.

The first part of the article presents the state of the question about the concept and evolution of the SC and its interweaving with geographic discipline; the current importance of DCT training and the work that has been done in other research. In the second part, we synthesize the main findings of the implemented intervention as well as the conclusions reached.

\subsection{The concept of space competence}

Defining the central concept of this research, "spatial competence", is essential for understanding the results that will later be offered.

The referential framework to define the competences is the declarations coming from the references [8,9], the reference [10] and as stated in [11] Report. Competency is understood as: "the development of complex capacities that allow students to think and to act in various fields [...]. It consists of acquiring knowledge through action, the result of a solid base culture that can be put into practice and used to explain what is happening" [12, p.35]. By spatial competence an aspect of intellectual capacity is recognized [13,14], "which is unitary in itself, but is composed of multiple sub-abilities that may be more or less accentuated in different people and that influence the level of achievement in various fields " [3, p. 67].

The spatial intelligence or SP, this includes the abilities to accurately perceive the visual world, carry out transformations and modifications of one's own initial perceptions, and recreate aspects of one's own visual experience, even in the absence of appropriate physical stimuli [15]. Thus, this competence emerges as an amalgamation of skills, which start from an elementary operation: the ability to perceive a form or object of reality [16, p.9].

\subsection{Spatial competence and geography}

In the field of education, works on Spatial Ability (SA) have focused on the areas of Science, Technology, Engineering and Mathematics (STEM domains) [17] and, in a special in geometry [18] and in engineering [19, 20]. 
SA or SP is a type of intelligence involved with objects. This, unlike logicalmathematical intelligence, which has a growing trajectory of abstraction, remains fundamentally linked to the concrete world and hence it is "staying power" [21, 22, p.43]. There are various proposals in relation to the elements that comprise it. Thus, various components of $\mathrm{HE}$ are recognized $[23,24]$ such as spatial perception; spatial visualization; mental rotations; spatial relationships and spatial orientation. The latter involves the ability of mentally locating an element in space and coming to preview it (think it) from different perspectives [25]. This ability is intimately linked to geographic discipline.

The subject "geography" promotes knowledge and training to: locate; represent the Earth's surface; correctly describe plans and maps interpreting their scale and conventional signs; identify and manage the concepts of parallels, meridians and geographic coordinates; locate on a map among others.

The SP plays an essential role in the development of new knowledge.

\subsection{Space competition and technologies}

In the current context, where the requirements for the formation of ICS citizenship are generating transformations in the field of education, the universities of the European Higher Education Area (EHEA) are striving to implement modifications in the models and methodologies of teaching and learning (LT). The objective is none other than the achievement of a higher education system adapted to the new needs in the field of technology, providing centers and departments with resources and Internet connectivity and paying special attention to the role of teachers and their digital competence since there are the teachers who, in this context, acquire a central role for the correct incorporation of new ICT resources [26, 27].

Technological resources can help in the learning and understanding of space in an autonomous way [28, 29]. As has already been pointed out, in the specific case of geographic science, spatial knowledge is essential since this structuring content is part of its essence. The distribution of phenomena in the territory has been the object of study, over time, of geography, constituting the main objective in formal school education. The GIT tools and their didactic application can develop educational programs that allow a comprehensive training of the students since they allow the physical environment to be brought closer to the student.

The criteria that drove the search for key publications to support the literature review have been, knowing what geospatial competence is (epigraph 1.1) And how it is conceptualized; show the relationship between this competence and the Geography discipline (epigraph 1.2) and relate spatial competence to the new demands of the ICS (epigraph 1.3).

In light of all the above, it is considered necessary, to help the training of future teachers, to carry out the analysis on the perception of a sample made up of teachers in training $(n=421)$, in relation to their DTC, SP and compare it with the assessment they make of a classroom practice with technology, to achieve these skills. That is why the purpose of this research has focused on the work, through different hardware (mobile devices) and software (geolocation), of the acquisition and development of 
the EC and the DTC in the training of future teachers. All this, supported by the T-L TAPCK model, validated with one of the most appropriate for the correct inclusion of technology in educational processes. Conclusions have been drawn that, although not definitive, provide important reflections for future research on the subject.

\section{$2 \quad$ Methodological Design}

\subsection{Design of the investigation}

The work has been approached from a descriptive approach, with a mixed methodology [30]. For its development, an exploratory-type research design based on the use of the questionnaire as a tool for collecting information [31] and experiential, based on the analysis of the proposed didactic designs [27]. The research has been developed during several academic courses, in the context of learning from the Faculty of Education of a Spanish university. The study process has been configured throughout four phases $[32,52]$ : theoretical review on CDDs, the TPACK model, GITs and previously developed studies on the concept of spatial-geospatial competence; the design and subsequent validation of the instrument based on the collaboration of faculty from other national and international universities; the subsequent collection of information through the questionnaire and the development of the geolocation practice and the analysis of the data.

\subsection{Sample}

The sample object of the study has been selected in a non-probabilistic, directed and intentional way [33], consisting of 421 participants, undergraduate and postgraduate teachers, coming from Spanish university institutions. The sample is considered significant with respect to the total existing population [34] and is made up of 301 women $(71.3 \%)$ and 120 men $(28.7 \%)$. The age range is between 19 years and over 40 years, distributed in six subgroups. In relation to the studies they carry out, 355 students are studying a Master's Degree in Primary Teacher and 66 a Master's Degree in Teachers.

\subsection{Instruments}

In this research, a methodological design based on survey-type studies was chosen, as well as a descriptive and inferential cross-sectional quantitative methodology. For this, two analysis tools have been used. On the one hand, a questionnaire has been applied, adapted to the objectives of the study and designed ad hoc, based on the one used by the Ref. [35] and the Ref. [32], whose content has been validated by experts from Spanish and international public universities. The instruments consist of 23 items measured on a five-point Likert scale (1, Strongly disagree - 5, Totally agree), and organized into five study dimensions: 1 . Socio-demographic characteristics (items $1-3)$; 2. Knowledge of Content (CK) (items 4-8); 3. Pedagogical Technological 
Knowledge (TPK) (9-13); 4. Technological Knowledge of Content (TCK) (items 1418); and 5. Pedagogical and Content Knowledge (PCK) (items 19-23) (Table 1).

To verify the reliability of the questionnaires, the Cronbach's alpha coefficient has been calculated. The results obtained $(\alpha=.918)$ confirm the existence of a high and adequate internal consistency of the instrument for the proposed study [36, 37]. In the same way, the Pearson's Chi-Square index was found with results of $\mathrm{p}$-value $<1=$ Sig. 0.001 [38], indicative of the high correlation of the questions posed, illustrative of the validity of the items and the structure of the instruments implemented.

Also, the didactic practice developed by the participating students, related to geolocation with Learning and Knowledge Technologies (LKT), with different hardware (mobile phones; tablets) and software (Google EarthTM; GPS Compass Explorer; GPAS Compass) has been evaluated. Navigator; Google EarthTM (GH), Google Maps (GM), QRCODE-Monkey).

\subsection{Procedure}

Regarding the procedure, first of all, permission was requested for its distribution, following the data treatment regulations Organic Law 15/1999, of December 13, on the Protection of Personal Data, Organic Law 3/2018, of December 5, on Personal Data Protection and guarantee of digital rights, and Regulation (EU) 2016/679 of the Parliament and of the European Council of April 27, 2016. Once the process was approved, the questionnaire was distributed, before and after practice (table 1). The medium used was the institutional email of the participants, through the free Google Forms application. It was distributed during the second semester of the various academic courses analyzed.

The conditions under which the study would be carried out, the research objectives and its duration were reported. After explaining the purpose of the investigation, participants were reminded of the confidentiality and anonymity with which the data obtained would be processed and interpreted.

Regarding the didactic proposal, a group practice was designed, outside the classroom, oriented to the work of the SP. The activity to be carried out consisted in the geolocation of relevant artistic-cultural milestones reflected in eight routes on the University Campus. Groups of 3-5 students were formed who were provided with one of the routes. Likewise, the indications regarding the necessary material for the development of the tasks and other aspects to be taken into account when carried out in a context other than the classroom were distributed; The process to follow to carry out a correct use of the GIT (mobile devices; preparation of QR; geolocation programs) as well as the delivery format of the final task were explained in detail. This information was transmitted to all participants prior to the practice and was posted in the Virtual Campus space available for the subject of "Teaching of Social Sciences: Geography", at the University. 
Table 1. Questionnaire, instrument of the research

\begin{tabular}{|c|c|c|}
\hline D. & Var. & Item \\
\hline \multirow{5}{*}{ 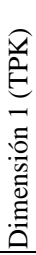 } & $\mathrm{CK}_{1}$ & I am able to define the concept of geographical "orientation". \\
\hline & $\mathrm{CK}_{2}$ & $\begin{array}{l}\text { I have abilities and skills to be able to orient myself in the geographical space from the } \\
\text { simple and complex cardinal points. }\end{array}$ \\
\hline & $\mathrm{CK}_{3}$ & $\begin{array}{l}\text { I have abilities and skills to be able to orient myself in the geographical space based on } \\
\text { cartographic coordinates. }\end{array}$ \\
\hline & $\mathrm{CK}_{4}$ & I am able to identify and manage the concepts of parallels, meridians. \\
\hline & $\mathrm{CK}_{5}$ & I am able to locate elements of the geographical space on a map and / or plane. \\
\hline & $\mathrm{TPK}_{1}$ & $\begin{array}{l}\text { The GIT resources used and the practices in which I have participated allow me to } \\
\text { choose the appropriate technologies to optimize the teaching of Geography, to locate a } \\
\text { place and orient myself. }\end{array}$ \\
\hline & $\mathrm{TPK}_{2}$ & $\begin{array}{l}\text { The GIT resources and content worked on in my training have prepared me to use infor- } \\
\text { mation technology to improve students' motivation to learn content such as orientation } \\
\text { and spatial location. }\end{array}$ \\
\hline & $\mathrm{TPK}_{3}$ & $\begin{array}{l}\text { The activities carried out and the knowledge acquired in my training has enabled me to } \\
\text { use the GIT in various activities for the teaching of Geography. }\end{array}$ \\
\hline & $\mathrm{TPK}_{4}$ & $\begin{array}{l}\text { The activities carried out and the knowledge acquired has formed me to be able to select } \\
\text { the appropriate GITs to optimize the teaching of the contents and skills related to geolo- } \\
\text { cation. }\end{array}$ \\
\hline & $\mathrm{TPK}_{5}$ & $\begin{array}{l}\text { The implementation of GITs in the teaching and learning of Geography enables us to } \\
\text { adaptively use technologies in various geospatial skills teaching activities. }\end{array}$ \\
\hline \multirow{5}{*}{ 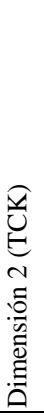 } & $\mathrm{TCK}_{1}$ & $\begin{array}{l}\text { The training received has enabled me to use specific software on geographic content } \\
\text { related to spatial location. }\end{array}$ \\
\hline & $\mathrm{TCK}_{2}$ & $\begin{array}{l}\text { The training and practices in which I have participated have taught me what information } \\
\text { technologies can be applied to teach how to orient in space. }\end{array}$ \\
\hline & $\mathrm{TCK}_{3}$ & $\begin{array}{l}\text { The activities in which I have participated have enabled me to use specific Geography } \\
\text { software to design geolocation activities. }\end{array}$ \\
\hline & $\mathrm{TCK}_{4}$ & $\begin{array}{l}\text { The activities carried out on location favor the acquisition of geospatial competences for } \\
\text { the selection of information technologies applicable to the teaching and learning of } \\
\text { Geography. }\end{array}$ \\
\hline & $\mathrm{TCK}_{5}$ & $\begin{array}{l}\text { The training received and the practices in which I have participated prepare to use specif- } \\
\text { ic Geography software to carry out activities related to geospatial competencies (locate, } \\
\text { orient, etc.). }\end{array}$ \\
\hline \multirow{5}{*}{ 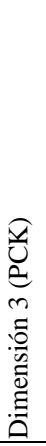 } & $\mathrm{PCK}_{1}$ & $\begin{array}{l}\text { The training received and the practices in which I have participated have taught me to } \\
\text { help students in solving problems related to geospatial skills. }\end{array}$ \\
\hline & $\mathrm{PCK}_{2}$ & $\begin{array}{l}\text { The training received and the practices carried out have enabled me to formulate specific } \\
\text { teaching objectives of the Geography curriculum related to geospatial competences. }\end{array}$ \\
\hline & $\mathrm{PCK}_{3}$ & $\begin{array}{l}\text { The training received and the practices in which I have participated have shaped me to } \\
\text { guide the students in carrying out activities in which to develop their geolocation skills } \\
\text { and abilities. }\end{array}$ \\
\hline & $\mathrm{PCK}_{4}$ & $\begin{array}{l}\text { The training received and the practices in which I have participated have prepared me to } \\
\text { determine which geographic concepts should be used in the school curriculum to achieve } \\
\text { the didactic objectives on location and spatial orientation. }\end{array}$ \\
\hline & $\mathrm{PCK}_{5}$ & $\begin{array}{l}\text { The training and practices in which I have participated enable me to select appropriate } \\
\text { GIT tools for evaluating student performance in learning content related to location and } \\
\text { spatial orientation. }\end{array}$ \\
\hline
\end{tabular}

Once the information of the groups was collected, the analysis of the data was carried out using the statistical package SPSS v.25. Taking into account the proposed objectives, different tests have been carried out. In an initial phase, the internal consistency of the questionnaire was assessed and the main descriptive statistics of the set 
of quantitative responses were obtained (mean $=M$ and standard deviation= SD). After that, an exploratory analysis of the descriptive test statistics was also carried out according to the dimensions that make up the instrument. In a second phase, the Student's t-test was applied for independent samples, to check if there were significant differences before and after the intervention.

\section{Results}

The analysis process has been organized and systematized. In section 3.1 Descriptive analysis, the data are presented with the following structuring and systematization: 1) the data process: a) the internal consistency of the questionnaire was assessed and the main descriptive statistics of the set of quantitative responses were obtained (mean= $\mathrm{M}$ and standard deviation= SD); b) After that, an exploratory analysis of the descriptive test statistics was also carried out according to the dimensions that make up the instrument; c) Student's t-test was applied for independent samples, to check if there were significant differences before and after the intervention.

\subsection{Descriptive analysis}

A selection of the results obtained in this study is presented. Starting with the descriptive analysis of the scores of the participants considering the items that make up the questionnaire, before (pre) and after the didactic intervention (post).

The comparison of the results of the descriptive statistics (mean = M; standard deviation $=\mathrm{SD}$ ) for each of the dimensions (Table 2) underlines an improvement in perception in all of them after the implemented practice.

In the CK dimension (items 4-8), which gives information on the perception of the students in relation to their geolocation knowledge, it is where the items present the most significant differences between the pre-questionnaire $(\mathrm{M} \geq 2.01 ; \mathrm{SD} \leq 0.784)$ and post ( $\mathrm{M} \geq 4.87 ; \mathrm{SD} \leq 0.582)$. These values indicate the poor training of the participants on content such as: location, orientation, parallels, meridians, etc.

Regarding the TPK dimension (items 9-13), the values show the negative perception of the participants, prior to the practice, in relation to their ability to understand and recognize the GIT resources and other appropriate technologies for the development of spatial competences in their teaching work $(\mathrm{M} \geq 3.44 ; \mathrm{SD} \leq 0.803)$. The values of the post questionnaire approximate the answer option "Totally agree" $(\mathrm{M} \geq 4.82$; $\mathrm{SD} \leq 0.563)$.

The same is true for the TCK dimension (items 14-18), where the sample considers that, prior to the intervention, it does not have sufficient knowledge about the pedagogical possibilities and limitations in the use of software and hardware to work with geolocation and to train in geospatial skills $(\mathrm{M} \geq 3.01 ; \mathrm{SD} \leq 0.772)$. Once the activity has been carried out, the response values (post) approach the option "Totally agree" $(\mathrm{M} \geq 4.81 ; \mathrm{SD} \leq 0.624)$. 
Table 2. Descriptive results ( $\mathrm{M}=$ mean, $\mathrm{SD}=$ standard deviation $)$ and $t$ de Student

\begin{tabular}{|c|c|c|c|c|c|c|c|}
\hline \multirow{2}{*}{$\begin{array}{c}\text { I } \\
\text { Item }\end{array}$} & & \multicolumn{2}{|c|}{ Pre phase } & \multicolumn{2}{|c|}{ Post phase } & \multicolumn{2}{|c|}{$t$ de Student } \\
\hline & & $M$ & $S D$ & $M$ & $S D$ & $t$ & Sig. unilateral \\
\hline \multicolumn{8}{|c|}{ Dimension 1 Knowledge of Content (CK) } \\
\hline Item 4 & $\mathrm{CK}_{1}$ & 2.03 & 0.665 & 4.98 & 0.532 & -4.059 & $0.000 * *$ \\
\hline Item 5 & $\mathrm{CK}_{2}$ & 2.65 & 0.634 & 4.99 & 0.545 & -3.580 & $0.007 * *$ \\
\hline Item 6 & $\mathrm{CK}_{3}$ & 2.72 & 0.658 & 4.97 & 0.527 & -4.109 & $0.000^{* * *}$ \\
\hline Item 7 & $\mathrm{CK}_{4}$ & 2.01 & 0.784 & 4.87 & 0.582 & -3.987 & $0.006^{* *}$ \\
\hline Item 8 & $\mathrm{CK}_{5}$ & 2.88 & 0.662 & 4.89 & 0.511 & -3.301 & $0.004 * *$ \\
\hline \multicolumn{8}{|c|}{ Dimension 2 Pedagogical Technological Knowledge (TPK) } \\
\hline Item 9 & $\mathrm{TPK}_{1}$ & 2.02 & 0.789 & 4.82 & 0.563 & -2.098 & $0.012 *$ \\
\hline Item 10 & $\mathrm{TPK}_{2}$ & 2.12 & 0.802 & 4.91 & 0.501 & -3.170 & $0.001 * *$ \\
\hline Item 11 & $\mathrm{TPK}_{3}$ & 3.01 & 0.734 & 4.88 & 0.544 & -4.896 & $0.000 * *$ \\
\hline Item 12 & $\mathrm{TPK}_{4}$ & 2.05 & 0.693 & 4.93 & 0.524 & -2.767 & $0.021^{*}$ \\
\hline Item 13 & $\mathrm{TPK}_{5}$ & 3.44 & 0.803 & 4.99 & 0.424 & -3.905 & $0.000 * *$ \\
\hline \multicolumn{8}{|c|}{ Dimension 3 Technological Knowledge of Content (TCK) } \\
\hline Item 14 & $\mathrm{TCK}_{1}$ & 3.09 & 0.713 & 4.93 & 0.502 & -4.701 & $0.000 * *$ \\
\hline Item 15 & $\mathrm{TCK}_{2}$ & 3.15 & 0.638 & 4.81 & 0.612 & -2.908 & $0.031 *$ \\
\hline Item 16 & $\mathrm{TCK}_{3}$ & 3.13 & 0.712 & 4.83 & 0.624 & -3.977 & $0.000 * *$ \\
\hline Item 17 & $\mathrm{TCK}_{4}$ & 3.01 & 0.642 & 4.96 & 0.522 & -2.014 & $0.029 *$ \\
\hline Item 18 & $\mathrm{TCK}_{5}$ & 3.14 & 0.772 & 4.99 & 0.504 & -3.802 & $0.001 * *$ \\
\hline \multicolumn{8}{|c|}{ Dimension 4 Pedagogical and Content Knowledge (PCK) } \\
\hline Item 19 & $\mathrm{PCK}_{1}$ & 3.15 & 0.698 & 4.88 & 0.624 & -3.991 & $0.000^{* *}$ \\
\hline Item 20 & $\mathrm{PCK}_{2}$ & 3.19 & 0.877 & 4.85 & 0.625 & -2.195 & $0.016^{*}$ \\
\hline Item 21 & $\mathrm{PCK}_{3}$ & 3.13 & 0.818 & 4.90 & 0.597 & -3.838 & $0.000 * *$ \\
\hline Item 22 & $\mathrm{PCK}_{4}$ & 3.12 & 0.784 & 4.83 & 0.627 & -4.090 & $0.000 * *$ \\
\hline Item 23 & $\mathrm{PCK}_{5}$ & 3.17 & 0.771 & 4.82 & 0.631 & -3.997 & $0.000 * *$ \\
\hline
\end{tabular}

Also, this same trend is observed in the PCK dimension (items 19-23), with response values, in the pre-questionnaire next to "Neither agree nor disagree" $(M \geq 3.12$; $\mathrm{SD} \leq 0.877$ ), indicative of the perception of the sample in relation to its potential to formulate didactic objectives, evaluation processes or resolution of doubts about geospatial competences. Similarly, after practice, the results for this same dimension are equivalent to value 5 on the Likert scale $(\mathrm{M} \geq 4.82 ; \mathrm{SD} \leq 0.631)$.

To determine if there are significant differences between the analyzed dimensions and taking into account the differences that have been seen in the descriptive results ( $\mathrm{M}$ and SD), we have proceeded to compare, using inferential statistics, the scores obtained in the variables of each phase (pre and post). To do this, we applied the Student's t-test for related samples (Table 2). Although not listed in the table, the parametric assumptions of homoscedasticity and normality have been verified. In this regard, indicate that the data of the homoscedasticity of the variables yields values compatible with the application of parametric tests. Regarding normality, the Kolmogorov-Smirnov test, the level of significance is greater than $0.05(\mathrm{p} \geq 0.09)$, adjusting to normal, so the Student t-test can be applied for related samples. Regarding the results of the parametric assumptions, we can observe the existence of statistical significance in all the variables regarding the differences between both phases of the study (pre and post). This denotes the positive assessment regarding the didactic pos- 
sibilities of the intervention carried out in the different dimensions that have been considered for the study.

However, the CK dimension has been the area where a greater difference between both phases is detected, with a clear improvement in the responses (Sig. Bilateral $\leq 0.007)$. Also, highlight the value of bilateral significance for items of the PCK dimension with a unilateral significance value of $\leq 0.016$.

\subsection{Analysis of the developed practice}

The elaborated didactic proposal highlights the difficulties that the Primary Grade students find when facing the work with GIT to learn the geographical space. In particular, the problem lies in the lack of education and training in geospatial skills.

Practice route example

Cardinal and cartographic location with Google Earth ${ }^{T M}$ place mark

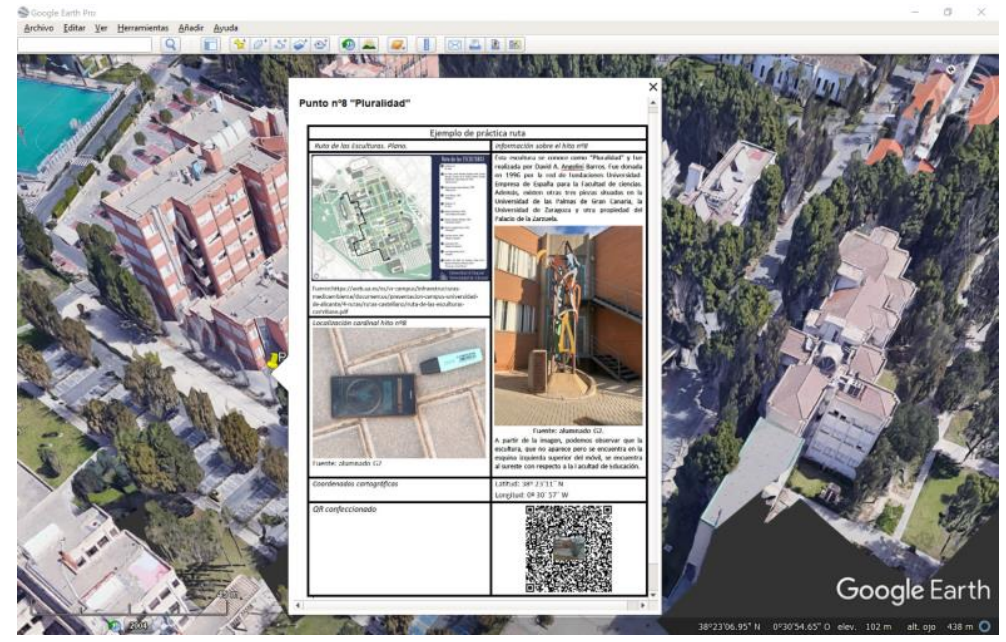

Fig. 1. Example of a developed proposal

The proposed practice has consisted of locating (cardinal and cartographic) landmarks on the University Campus. To do this, groups of students have been organized to whom they have been provided with a map, with the elements that they had to geolocation in order to subsequently make a QR with the following information: location (cardinal and cartographic) of the landmark; information related to said spatial element; image of said milestone; geolocation in Google EarthTM.

For the evaluation of the practice, a rubric was used, adapted to the research and validated by experts from various national and international universities (Table 3 ). 
Table 3. Aspects evaluated in the geolocation rubric

\begin{tabular}{|c|l|}
\hline D. & \multicolumn{1}{|c|}{ Evaluated elements } \\
\hline CK & $\begin{array}{l}\text { Recognition of the basic and complex cardinal points. } \\
\text { Correctly uses the concept of cardinal orientation (N, S, E and W). } \\
\text { Recognizes and understands cartographic coordinates (latitude and longitude). } \\
\text { Use cartographic coordinates to locate a point in space and on the plane. }\end{array}$ \\
\hline TPK & $\begin{array}{l}\text { Recognizes and properly uses the orientation and location of points on the plane. } \\
\text { GIT resource manipulation: GPS Compass Explorer; GPAS Compass Navigator; Google } \\
\text { Earth }\end{array}$ \\
$\begin{array}{l}\text { Use GH for geologle Maps (GM), QRCODE-Monkey. } \\
\text { Select those GITs and the appropriate ICT resources for geolocation of landmarks on the map. }\end{array}$ \\
\hline TCK & $\begin{array}{l}\text { Use software and hardware resources to work on geographic content related to in situ spatial } \\
\text { orientation and location. } \\
\text { It solves the task of orientation and spatial location in the plane, based on the acquisition of } \\
\text { geospatial skills. }\end{array}$ \\
\hline PCK & $\begin{array}{l}\text { Use your geolocation skills and abilities to solve the practice. } \\
\text { Recognizes Geography content related to location and spatial orientation. } \\
\text { Demonstrates the achievement of geospatial skills geolocating landmarks in space, from the } \\
\text { plane. }\end{array}$ \\
\hline
\end{tabular}

\section{Discussion and Conclusions}

The potential of geospatial information and its interest in citizenship is closely linked with decision-making and management [39], and also for professional development [40].

Along with geospatial skills, training in the use, manipulative, critical and informative of technologies is a fundamental element in the development of current T-L processes. In this context, the teachers must possess a series of knowledge with which they can develop an effective and efficient educational integration of technologies [41]; directed towards their teaching practices; taking into account the theories on which pedagogy is supported without neglecting a deep knowledge of the contents of its discipline. The complementarity of all these requirements is the basis of the T-L TPACK model [26, 42]. From the interrelation of the dimensions of the model (disciplinary knowledge (CK); pedagogical (PK) and technological knowledge (TK) and their combinations (PCK, TCK, TPK)), it is sought that teachers build enriched learning environments, which favors the achievement of the educational objectives set.

It is necessary, therefore, to address the correct training of future teachers so that they have DTC and, in the specific case of Social Sciences, with SP [27]. That is why this study investigates the current situation with respect to the knowledge that future teachers possess in three dimensions of the TPACK model: disciplinary knowledge about geospatial competence of teachers in training before and after the course (CK); knowledge about their digital teaching competence (TCK) and their perception about its manipulative, didactic and pedagogical importance (TPK and PCK).

The results obtained in this research show that the teachers, participants in the study, have a poor geospatial competence (CK dimension) when they begin their preparation as future teachers (Bachelor's and Master's Degrees). Once strategies and activities oriented to the development of their SP with GIT have been implemented in 
their training, this training improves substantially, providing future teachers with such geospatial competencies as confirmed in this work. Such results converge with the research of other authors, in relation to higher technical studies [3, 43] and humanities $[44,45]$.

Similarly, we detect that there is little training in the sample in methodologies that adequately combine content and technology (PCK dimension). On the contrary, and responding to another of the objectives set out in this work, the values obtained show a positive perception of the students about their professional capacity in digital skills (TPK dimension) and in the use of technologies for teaching geospatial contents (TCK dimension). Similar conclusions were reached by other researchers [46, 26] who confirm that teachers in training do not present difficulties in manipulating digital devices. This perception may be due to the fact that future teachers tend to interpret the manipulative use of technologies and their digital training as teachers in two different fields, decoupling the teaching skills themselves from the teachers' digital skills.

Another objective of the study has been the analysis of the ability of new teachers to select technological resources, appropriate to specific contents. Thus, the study presents a deficient capacity to discern how to implement, appropriately, the ICT and GIT resources, for the transmission of content related to location and orientation (PCK dimension) prior to the intervention. After the training received, a clear improvement is confirmed in relation to the adequate selection of GIT tools for working with geolocation content and the qualification of the participants to implement the technologies in the classroom (TCK) is accredited.

In the same way, the value that the training teachers place on such training is corroborated. These findings coincide with other studies [47, 8, 27], where the need for digital teacher training and its benefits for teaching is stated, as well as the importance of adapting the study plans to such ICS requirements [4, 46, 48, 42].

All these evidences allow us to conclude that, despite the importance of teaching citizenship about spatial capacity, in order to associate and relate contents that may not have a direct relationship at first, university curricula continue without betting on classroom practices that serve, concretely, to such requirements. Likewise, and despite the positive self-efficacy in digital skills of future teachers, the lack of adequacy of the undergraduate and postgraduate curriculum proposals of teachers for the correct implementation of GIT in initial training is verified. In this sense, although the educational administrations are carrying out proposals for the improvement in the training and implementation of technologies in the university study plans [27], there is still a long way to go to comply with the current demands of the ICS. It is essential, for educational improvement and understanding of geographic space, to enhance skills related to digital competence such as the recovery, selection, creation or exchange of digital content and experiences in virtual environments [50,51, 26, 49,53]; and with geospatial skills.

Regarding the limitations of this work, it must be said that it is partial data, since it is an incipient, wide-ranging investigation that will last over time, for at least two academic years. 
It should also be noted that it would be interesting, in future analysis, to assess the qualitative and perception results by gender in order to evaluate possible variations based on this factor. Similarly, it would be interesting to investigate the relationship between the beliefs and practices of future teachers, extending the study to active teachers.

\section{$5 \quad$ Acknowledgement}

This research has been carried out under the umbrella of the Research Group of the University of Alicante of New teaching contexts from ICT and LKT with TPACK: interdisciplinary as a methodology in $21 \mathrm{st}$ century teacher training (REDESI3CE2020-4612), directed by Dra. Isabel María Gómez Trigueros.

\section{References}

[1] D.S. Rychen, L. Hersh, and J. Userkonstant, Definición y Selección de las Competencias (DeSeCo): Fundamentos teóricos y conceptuales de las competencias. París: OCDE, 2003.

[2] M.C. Linn, and A.C. Petersen, "Emergence and characterization of sex differences in spatial ability: A meta-analysis," Child development, no. 2, Feb., pp. 1479-1498, 1985. [Online], Available: https://www.jstor.org/stable/1130467?seq=1[Accessed April. 15, 2020]. https://doi.org/10.2307/1130467

[3] S. Vázquez, and M. Noriega, "La competencia espacial. Evaluación en alumnos de nuevo ingreso a la Universidad," Educación Matemática, vol. 22, no. 2, pp. 65-91, 2010. [Online], Available: http://www.scielo.org.mx/pdf/ed/v22n2/v22n2a4.pdf. [Accessed April. 11, 2020].

[4] P. Mishra, and M.J. Koehler, "Technological Pedagogical Content Knowledge: A new framework for teacher knowledge," Teachers College Record, vol. 108, no. 6, pp. 10171054, 2006. https://doi.org/10.1111/j.1467-9620.2006.00684.x

[5] S.L. Shulman, "Knowledge and Teaching. Foundations of the New Reform," Harvard Educational Review, 57, PP.1-22, 1987.

[6] S. Järvelä, P. Näykki, L. Laru, and T. Luokkanen, "Structuring and regulating collaborative learning in higher education with wireless networks and mobile tools," Educational Technology y Society, vol. 10, no. 4, pp.71- 79, 2007. [Online], Available: https://www. learntechlib.org/p/74886/. [Accessed April. 09, 2020].

[7] I.M. Gómez-Trigueros, M. Ruiz-Bañuls, and D. Ortega-Sánchez, "Digital Literacy of Teachers in Training: Moving from ICTs (Information and Communication Technologies) to LKTs (Learning and Knowledge Technologies)," Education Sciences, vol. 9, no. 4, pp. 274, 2019. https://doi.org/10.3390/educsci9040274

[8] UNESCO, "Enfoque por Competencias, Oficina Internacional de Educación ”. UNESCO, 2007. [Online]. Available: http://www.ibe.unesco.org/es/comunidades/comunidad-de-prac ticacop/enfoque-por-competencias.html. https://doi.org/10.4272/978-84-9745-267-0.ch1

[9] UNESCO, "Las competencias en el desarrollo curricular," UNESCO, 2013. [Online]. Available: http://www.ibe.unesco.org/cops/Competencies/Competencias_esp.pdf. [Accessed Feb.7, 2020]. 
[10] OCDE, Working Paper 21st Century Skills and Competences for New Millennium Learners in OECD Countries. EDU Working paper. Paris: Instituto de Tecnologías Educativas, 2010. https://doi.org/10.1787/218525261154

[11] J. Delors, La Educación encierra un Tesoro. Madrid: Editorial Santillana, Ediciones UNESCO, 1996.

[12] C. Braslavsky, and F. Acosta, "La Formación en Competencias para la Gestión de la Política Educativa: un Desafío para la Educación Superior en América Latina," REICE. Revista Iberoamericana sobre Calidad, Eficacia y Cambio en Educación, vol. 4, no. 2, pp. 27-42, 2006. [Online], Available: https://www.redalyc.org/pdf/551/55140203.pdf. [Accessed April. 08, 2020]. https://doi.org/10.15366/reice2020.18.2.006

[13] D.F. Lohman, "The effect of speed-accuracy tradeoff on sex differences in mental rotation," Perception and Psychophysics, vol. 39, no. 6, pp. 427-436, 1986. https://doi.org/10. 3758/bf03207071

[14] D.F. Lohman, "Human intelligence: An introduction to advances in theory and research," Review of Educational Research, vol. 59, no. 4, pp.333-373, 1989. [Online], Available: https://doi.org/10.2307/1170203. [Accessed April. 02, 2020].

[15] H. Gardner, Frames of mind: The theory of Multiple Iintelligences. New York: Basic Books, 1983.

[16] M. Dziekonski, "La inteligencia espacial: Una mirada a Howard Gardner," ArteOficio, no. 2, pp. 7-12, 2012. [Online], Available: http://www.revistas.usach.cl/ojs/index.php/arteofic io/article/view/812/766. [Accessed January 15, 2020].

[17] J. Wai, D. Lubinski, and C.P. Benbow, "Spatial ability for STEM domains: Aligning over 50 years of cumulative psychological knowledge solidifies its importance," Journal of educational psychology, vol. 101, no. 4, pp. 817-821, 2009. https://doi.org/10.1037/a0016127

[18] C. Schelly, G. Anzolone, B. Wijnen, and J.M. Pearce, "Open-source 3-D printing technologies for education: bringing additive manufacturing to the classroom," Journal of Visual Languages \& Computing, No. 28, pp. 226-237, 2015. [Online], Available: https://digitalcommons.mtu.edu/cgi/viewcontent.cgi?article=1046\&context=materials_fp. [Accessed Feb. 21, 2020]. https://doi.org/10.1016/j.jvlc.2015.01.004

[19] J. Martín-Gutiérrez, M. García-Domínguez, C. Roca-González, A. Sanjuán-Hernán Pérez, and C. Mato-Carrodeguas, "Comparative Analysis Between Training Tools in Spatial Skills for Engineering Graphics Students Based in Virtual Reality, Augmented Reality and PDF3D Technologies," Procedia Computer Science, no. 25, pp. 360-363, 2013. [Online], https://doi.org/10.1016/j.procs.2013.11.043

[20] J. Torner, F. Alpiste, and M. Brigos, "Spatial Ability in Computer-Aided Design Courses," Computer-Aided Design and Applications, vol. 12, no. 1, pp. 36-44, 2014. https://doi.org /10.1080/16864360.2014.949572

[21] H. Gardner, Intelligence Reframed: Multiple Intelligences for the 21st Century. Nueva York, Basic Books, 1999. https://doi.org/10.4995/thesis/10251/11796

[22] A. Villa, Desarrollo y evaluación de las habilidades espaciales de los estudiantes de Ingeniería. Actividades y estrategias de resolución de tareas espaciales. Tesis Doctoral. Barcelona: Universitat Politécnica de Catalunya, 2016. https://doi.org/10.4995/thesis/10251/11 $\underline{796}$

[23] M.G. McGee, "Human spatial abilities: psychometric studies and environmental, genetic, hormonal, and neurological influences," Psychological bulletin, vol. 86, no.5, pp. 889-918, 1979. https://doi.org/10.1037/0033-2909.86.5.889

[24] P.H. Maier, "Spatial geometry and spatial ability-How to make solid geometry solid?" In Annual Conference of Didactics of Mathematics, Munich, Germany: Gessellschaft für Didaktik der Mathematik (GDM), 1996, pp. 63-75. 
[25] M. Hegarty, and D.A. Waller, Individual differences in spatial abilities. The Cambridge Handbook of Visuospatial Thinking. Cambridge: Cambridge University Press, 2005. https ://doi.org/10.1017/cbo9780511610448.005

[26] I.M. Gómez-Trigueros, "Methodologies Gamified as Didactic Resources for Social Sciences," International Journal of Emerging Technologies in Learning. iJET, vol. 14, no. 23, pp. 193-207, 2019. [Online], Available: https://online-journals.org/index.php/ijet/article/view/10794/6205 https://doi.org/10.3991/ijet.v14i23.10794

[27] I.M. Gómez-Trigueros, and J. Binimelis, "Aprender y enseñar con la escala del mapa para el profesorado de la "generación Z": la competencia digital docente," Ar@cne: revista electrónica de recursos en internet sobre geografía y ciencias sociales, no. 1, 2020. [Online], Available: https://www.raco.cat/index.php/Aracne/article/view/362307 [Accessed March 09, 2020]. https://doi.org/10.1344/ara2020.238.30561

[28] J.C. Giraldo Restrepo, "La cartografía en el ámbito de las Tecnologías de la Información y la Comunicación (TIC)," Revista DIM, no. 31, pp. 1-18, 2015. [Online], Available: https://ddd.uab.cat/record/131904 https://doi.org/10.2307/j.ctv8xnjck.7

[29] J. Fombona, and E. Vázquez-Cano, "Posibilidades de utilización de la geolocalización y realidad aumentada en el ámbito educativo," Educación XX1, vol. 20, no.2, pp. 319-342, 2017. [Online], Available: https://doi.org/10.5944/educxx1.19046 [Accessed March 9, 2020].

[30] M.C. Sánchez-Gómez, A.I. Rodrigues, and A. P. Costa, "Desde los métodos cualitativos hacia los modelos mixtos: tendencia actual de investigación en ciencias sociales," Revista Ibérica de Sistemas e Tecnologias de Informação, no. 28, pp. 9-13, 2018. [Online], Available: https://doi.org/10.17013/risti.28.0

[31] A. Pardo, M.A. Ruiz, and R. San-Martín, Análisis de datos en ciencias sociales y de la salud I. Madrid: Síntesis, 2015.

[32] I.M. Gómez-Trigueros, "El modelo TPACK en los estudios de Grado para la formación inicial del profesorado en TIC," Didáctica Geográfica, no.16, pp. 185-201, 2015. . [Online], Available: http://didacticageografica.age-geografia.es/index.php/didacticageogr afica/article/download/310/285 https://doi.org/10.6018/reifop.16.2.180761

[33] J.C. Argibay, "Muestra en investigación cuantitativa," Subjetividad y Procesos Cognitivos, vol. 13, no. 1, pp. 13-29, 2009. https://www.redalyc.org/pdf/3396/339630252001.pdf [Accessed March 2, 2020].

[34] L. Buendía, M.P. Colás, and F. Hernández, Métodos de investigación en Psicopedagogía. Madrid: McGraw-Hill, 1998.

[35] D.A. Schmidt, E. Baran, A.D. Thompson, M.J. Koehler, P. Mishra, and T. Shin, “Technological pedagogical content knowledge (tpack): The development and validation of an assessment instrument for preservice teachers," Journal of Research on Technology in Education, vol. 42, no. 2, pp. 123-149, 2009. https://doi.org/10.1080/15391523.2009.10782544 [Accessed March 18, 2020].

[36] R. Hernández, C. Fernández, and M.P. Baptista, Metodología de la investigación. México, D.F.: McGraw-Hill, 2010.

[37] R. Bisquerra, Metodología de la investigación educativa, Madrid: La Muralla, 2004.

[38] L.Cohen, L. Manion, and K. Morrison, Research methods in education. London: Routledge, 2007.

[39] P. Muro-Medrano, "Etapas de la popularización de las infraestructuras de información geoespacial," GeoFocus, Revista Internacional de Ciencia y Tecnología de la Información Geográfica, no. 12, pp. 1-5, 2012. [Online], Available: http://www.geofocus.org/index. php/geofocus/issue/view/13 [Accessed March 6, 2020]. https://doi.org/10.21138/gf.682 
[40] M.H. Tsou, and K. Yanow, "Enhancing General Education with Geographic Information Science and Spatial Literacy," URISA Journal, vol. 22, no. 2, pp. 45-55, 2010. [Online], Available:https://geoinfo.sdsu.edu/hightech/Images/URISAjournal/2010-Tsou-Yanow-UR ISA\%20Journal\%20Vol.22\%20Issue\%202.pdf [Accessed April 14, 2020].

[41] J. Campos, and W. Solano, "The future of the teaching profession from the perspective of students with a Major in Education," Journal of New Approaches in Educational Research, vol. 6, no. 2, pp. 87-92, 2017.http://doi.org/10.7821/naer.2017.7.191 [Accessed April 15, 2020].

[42] D. Ortega-Sánchez and I.M. Gómez-Trigueros, "Didactics of Historical-Cultural Heritage QR Codes and the TPACK Model: An Analytic Revision of Three Classroom Experiences in Spanish Higher Education Contexts," Education Sciences, vol. 9, no. 2, pp. 117, 2019. [Online], Available: https://doi.org/10.3390/educsci9020117 [Accessed April 18, 2020]. https://doi.org/10.3390/educsci9020117

[43] S. Vázquez, M. Noriega, and S. Maris, "Relaciones entre rendimiento académico, competencia espacial, estilos de aprendizaje y deserción," REDIE, vol. 15, no. 1, pp. 29-44, 2013. [Online], Available: http://redie.uabc.mx/vol15nol/contenido-vazqueznoriega.html [Accessed Feb. 24, 2020].

[44] D. Llancavil, and J. González, "Un enfoque didáctico para la enseñanza del espacio geográfico," Revista Electrónica Diálogos Educativos, vol. 14, no. 28, pp. 64-91, 2017. http ://revistas.umce.cl/index.php/dialogoseducativos/article/view/1029 [Accessed Feb. 25, 2020].

[45] R. Cebolla, E. Gómez, and F. López, “Aprendiendo Geografía con una IDE didáctica. Los geojuegos de IDEARAGON,” Revista MAPPING, vol. 26, no. 182, pp. 26-36, 2017. http:// revistas.revistamapping.com/MAPPING_182/MAPPING_182.html [Accessed Feb. 28, 2020].

[46] R. Roig-Vila, S. Mengual, C. Sterrantino, and P. Quinto, "Actitudes hacia los recursos tecnológicos en el aula de los futuros docents," @tic. Revista d'innovació educativa, no. 15, pp. 12-19, 2015. [Online], Available: https://doi.org/10.7203/attic.15.7220 [Accessed March 30, 2020]. https://doi.org/10.7203/attic.15.7220

[47] S. Emine, Ü. Emre, and İ. Kamil, "Primary School Second Grade Teachers' and Students' Opinions on Media Literacy," Comunicar, vol. 21, no. 42, pp. 119-127, 2014. [Online], Available: http://doi.org/10.3916/C42-2014-11 [Accessed March 25, 2020].

[48] J. Cabero, and J. Ruiz, "Las Tecnologías de la Información y Comunicación para la inclusión: reformulando la brecha digital," Ijeri. International Journal of Educational Research and Innovation, no. 9, pp. 16-30, 2017. [Online], Available: http://orcid.org/00000002-6958-0926 [Accessed April 15, 2020]. https://doi.org/10.46661/ijeri.4407

[49] N. Wahyuningtyas, and I. Idris, "Increasing Geographic Literacy through the Development of Computer Supported Collaborative Learning," International Journal of Emerging Technologies in Learning. iJET,vol. 15, no. 7, pp. 74-85, 2020. [Online], Available: https:// online-journals.org/index.php/i-jet/article/view/13255/6827 [Accessed April 15, 2020]. https://doi.org/10.3991/ijet.v15i07.13255

[50] M.C. Martínez-Bravo, Ch. Sádaba, and J. Serrano-Puche, "Desarrollo de competencias digitales en comunidades virtuales: un análisis de "ScolarTIC"," Prisma Social. Revista de Ciencias Sociales e Investigación Social, vol. 20, pp. 129-159, 2018. [Online], Available: https://revistaprismasocial.es/article/view/2318 [Accessed Feb. 12, 2020].

[51] M.P. Colás-Bravo, J. Conde-Jiménez, and S. Reyes-Cózar, "The development of the digital teaching competence from a sociocultural approach," Comunicar, vol. 27, no. 61, pp. 2132, 2019. [Online], Available: https://doi.org/10.3916/C61-2019-02 [Accessed Feb. 8, 2020]. 
[52] H. Andyani, P. Setyosari, and B. B. Wiyono, "Does Technological Pedagogical Content Knowledge Impact on the Use of ICT in Pedagogy?" Int. J. Emerg. Technol. Learn. IJET, vol. 15, no. 03, pp. 126-139, 2020. [Online], Available: https://doi.org/10.3991/ijet.v15i03 .11690. [Accessed Feb. 29, 2020].

[53] St. Papadakis, and M. Kalogiannakis, (2017). "Combining mobile technologies in environmental education: A Greek case study," International Journal of Mobile Learning and Organisation, (Special Issue on Mobile Learning Applications and Strategies), vol. 11, no. 3, pp. 256-277. https://doi.org/10.1504/IJMLO.2017.10003925[Accessed Juny 05, 2020]. https://doi.org/10.1504/ijmlo.2017.10005249

\section{$7 \quad$ Author}

Isabel María Gómez Trigueros is a teacher in the Department of Didactics of Social Sciences of the Faculty of Education of the University of Alicante (Spain). She leads the Educational Innovation Project of the Vice Chancellor for Innovation and Research of the University of Alicante and the Institute of Education Sciences of the University of Alicante: "New teaching contexts from ICT and LKT with TPACK: interdisciplinarity as a methodology in $21 \mathrm{st}$ century teacher training" (REDESI3CE2020-4612).

Article submitted 2020-04-16. Resubmitted 2020-06-10. Final acceptance 2020-06-10. Final version published as submitted by the authors. 